\title{
Assessment of Correlation and Path Coefficient Analysis for Yield and it's Attributing Traits in Rice (Oryza sativa L.) Genotypes
}

\author{
Deepak Meena ${ }^{1}$, Manoj Kumar ${ }^{1 *}$, Sandhya $^{1}$, N. R. Koli ${ }^{1}$, \\ Yamini Tak ${ }^{2}$ and Ashok Kumar Meena ${ }^{1}$ \\ ${ }^{1}$ Department of Genetics and Plant Breeding, ${ }^{2}$ Department of Biochemistry, Agriculture \\ University Kota, India \\ *Corresponding author
}

\begin{abstract}
A B S T R A C T
\section{Keywords}

Correlation and Path Coefficient Analysis, Rice (Oryza sativa L.)

Article Info

Accepted:

22 June 2020

Available Online:

10 July 2020

Present investigation was carried out to examine the association and path analysis for grain yield and its attributing traits in 25 rice genotypes. The result of character association revealed that number of productive tillers per plant $\left(r_{p} 0.881 \& r_{p} 0.993\right)$ exhibited highly significant and positive correlation with grain yield per plant followed by 1000-grains weight ( $\left.r_{p} 0.607 \& r_{g} 0.645\right)$, panicle length $\left(r_{p} 0.369 \& r_{g} 0.459\right)$, plant height $\left(r_{p} 0.284 \&\right.$ $\left.r_{g} 0.409\right)$, days to maturity $\left(r_{p} 0.293 \& r_{g} 0.325\right)$ and days to 50 per cent flowering $\left(r_{p} 0.294\right.$ $\left.\& r_{g} 0.308\right)$ at phenotypic as well as genotypic level respectively proving that grain yield could be enhanced by selecting genotypes containing higher values for these attributes. The path analysis result showed that the maximum direct positive effect on the grain yield per plant was exerted by number of productive tillers per plant followed by 1000-grain weight, panicle length, plant height, days to maturity and days to 50 percent flowering. These characters also exhibited prominent role as indirect effects of most component traits on grain yield per plant hence these traits should be considered as an essential selection criteria toward optimizing crop yield.
\end{abstract}

\section{Introduction}

Rice (Oryza sativa L.) is self-pollinated, annual cereal crop of the Poaceae family.It has $2 n=24$ chromosome number. The genus Oryza consisted of a total of 25 recognized species of which, 23 are wild species and two Oryza sativa and Oryza glaberrima are cultivated. Rice is the second most consumed cereal crop and staple food in the world for even more than $60 \%$ of the global inhabitants, delivering around $75 \%$ of calories as well as $55 \%$ of dietary protein in their regular normal intake. Almost $90 \%$ of the world's rice is produced mostly in Asian continent, therefore Asia is recognized as the world's rice bowl. In India rice occupied approximately 43.79 mha of area with production of 116.42 million tones and productivity nearly $2650 \mathrm{~kg} / \mathrm{ha}$. (Anonymous 2018-19).In Rajasthan rice cultivated on 0.199 million hectares area with the production of $0.46 \mathrm{million}$ tones and productivity of $2310 \mathrm{~kg} / \mathrm{ha}$ during( Anonymous 2018-19).Demand of rice is steadily increasing due to unhindered 
population expansion. In order to cope with the already-increasing population and selfsufficiency in rice production and perhaps to retain price stability, new varieties that might crack the yield ceiling are desperately required to develop.

Yield is a complex polygenic character largely influenced by its various component characters as well as by the environment. Hence, it becomes essential to estimate association of the yield with component characters and among themselves.

The efficiency of selection thus can be increased, if it is simultaneously practiced for characters which are correlated with yield. In the quantitative traits, the genotypes are influenced by the environment, thereby, affecting the phenotypic expression as well as association and consequently direction of association between the characters. The knowledge of magnitude and direction of correlation is used for judging how improvement in one character will bring simultaneous change in the other characters.

The correlation analysis provide an information which is incomplete in the sense that it does not throw light on the underlying cause that are operative for the various interrelationship. The expression of a complex character such as grain yield per plant depends upon the interaction of a number of component attributes.

A better picture of the contribution of each component building up the total genetic architecture of a complex character may be obtained through the analysis of causal schemes. Hence, in such a situation path coefficient analysis devised by Wright (1921) had been useful in partitioning direct and indirect causes of association which allow a detailed examination of specific forces acting to produce a given correlation and measures of the relative importance of each causal character. Such a study provides a realistic basis for allocation of weightage to each attributes in deciding a suitable criterion for genetic improvement. The analysis of correlation coefficient along with information on path coefficient helps considerably in identification of suitable characters for yield enhancement.

\section{Materials and Methods}

The experiment was carried out at Agriculture Research Station, Kota, Rajasthan. The experimental materials comprised of twenty five genotypes of rice. These genotypes were grown in a Randomized Block Design (RBD) with three replications during Kharif 2019. Twenty four days old seedlings were transplanted in 10 rows of $5 \mathrm{~m}$ length having plant to plant and row to row distance $20 \mathrm{~cm}$. and $10 \mathrm{~cm}$, respectively. All necessary precautions were taken to maintain uniform plant population in each treatment and in each replication.

Observations were recorded for the characters viz., days to 50 per cent flowering, days to maturity, plant height, number of productive tillers per plant, panicle length, number of grains per panicle, 1000-grains weight, amylose content $(\%)$, protein content $(\%)$, and grain yield per plant. The mean values of data was used for statistical analysis of correlation and path coefficient as per suggested by Singh and Chaudhary (1979) and Dewey and Lu (1959), respectively.

\section{Results and Discussion}

The association result revealed that genotypic correlation coefficients were higher than their corresponding phenotypic correlation coefficient which might be from the modifying effect of environment on the association of characters at phenotypic level (Table.1). 
Table.1 Estimation of Phenotypic (P) and Genotypic (G) correlation coefficient for 10 Characters of Rice

\begin{tabular}{|c|c|c|c|c|c|c|c|c|c|c|c|}
\hline Characters & $\mathbf{R}$ & $\begin{array}{c}\text { Days to } \\
50 \% \\
\text { flowering }\end{array}$ & $\begin{array}{l}\text { Days to } \\
\text { Maturity }\end{array}$ & $\begin{array}{c}\text { Plant } \\
\text { height } \\
\text { (cm.) }\end{array}$ & $\begin{array}{c}\text { Number of } \\
\text { productive } \\
\text { tillers per } \\
\text { plant }\end{array}$ & $\begin{array}{c}\text { Panicle } \\
\text { length } \\
\text { (cm.) }\end{array}$ & $\begin{array}{c}\text { Number } \\
\text { of grains } \\
\text { per } \\
\text { panicle }\end{array}$ & $\begin{array}{l}\text { 1000- } \\
\text { grain } \\
\text { weight } \\
\text { (g) }\end{array}$ & $\begin{array}{c}\text { Amylose } \\
\text { content } \\
(\%)\end{array}$ & $\begin{array}{c}\text { Protein } \\
\text { content } \\
(\%)\end{array}$ & $\begin{array}{c}\text { Grain yield } \\
\text { per plant } \\
\text { (g) }\end{array}$ \\
\hline \multirow{2}{*}{$\begin{array}{l}\text { Days to } 50 \% \\
\text { flowering }\end{array}$} & $\mathbf{P}$ & 1.000 & $0.976^{* * *}$ & $0.754^{* *}$ & $0.302^{* *}$ & $0.585^{* *}$ & $0.694^{* *}$ & $0.362^{* *}$ & $-0.446^{* *}$ & -0.074 & $0.294^{* *}$ \\
\hline & $\mathbf{G}$ & 1.000 & $0.999^{* *}$ & $0.926^{* *}$ & $0.329^{* *}$ & $0.631^{* *}$ & $0.961^{* *}$ & $0.372^{* *}$ & $-0.481^{* *}$ & -0.089 & $0.308 * *$ \\
\hline \multirow{2}{*}{$\begin{array}{l}\text { Days to } \\
\text { maturity }\end{array}$} & $\mathbf{P}$ & & 1.000 & $0.767^{* *}$ & $0.323^{* *}$ & $0.632^{* *}$ & $0.677^{* *}$ & $0.415^{* *}$ & $-0.418^{* *}$ & -0.040 & $0.293^{* *}$ \\
\hline & $\mathbf{G}$ & & 1.000 & $0.941^{* *}$ & $0.348^{* *}$ & $0.668^{* *}$ & $0.988^{* *}$ & $0.430^{* *}$ & $-0.446^{* *}$ & -0.036 & $0.325^{* *}$ \\
\hline \multirow{2}{*}{$\begin{array}{l}\text { Plant height } \\
\text { (cm) }\end{array}$} & $\mathbf{P}$ & & & 1.000 & $0.280^{*}$ & $0.567^{* *}$ & $0.526^{* *}$ & $0.411^{* *}$ & $-0.331^{* *}$ & -0.101 & $0.284^{*}$ \\
\hline & $\mathbf{G}$ & & & 1.000 & $0.383^{* *}$ & $0.705^{* *}$ & $0.859^{* *}$ & $0.534^{* *}$ & $-0.433^{* *}$ & -0.133 & $0.409^{* *}$ \\
\hline \multirow{2}{*}{$\begin{array}{l}\text { Number of } \\
\text { productive } \\
\text { tillers per } \\
\text { plant }\end{array}$} & $\mathbf{P}$ & & & & 1.000 & $0.396^{* *}$ & 0.197 & $0.527^{* *}$ & 0.117 & 0.214 & $0.881^{* *}$ \\
\hline & $\mathbf{G}$ & & & & 1.000 & $0.484^{* *}$ & $0.233 *$ & $0.577^{* *}$ & 0.124 & 0.210 & $0.993^{* *}$ \\
\hline \multirow{2}{*}{$\begin{array}{l}\text { Panicle } \\
\text { length }(\mathrm{cm})\end{array}$} & $\mathbf{P}$ & & & & & 1.000 & $0.375^{* *}$ & $0.622^{* *}$ & 0.048 & 0.031 & $0.369^{* *}$ \\
\hline & $\mathbf{G}$ & & & & & 1.000 & $0.518^{* *}$ & $0.677^{* *}$ & 0.057 & 0.058 & $0.459^{* *}$ \\
\hline \multirow{2}{*}{$\begin{array}{l}\text { Number of } \\
\text { grains per } \\
\text { panicle }\end{array}$} & $\mathbf{P}$ & & & & & & 1.000 & $0.262^{*}$ & $-0.334^{* *}$ & 0.066 & 0.146 \\
\hline & $\mathbf{G}$ & & & & & & 1.000 & $0.340^{* *}$ & $-0.488^{* *}$ & 0.067 & 0.204 \\
\hline \multirow{2}{*}{$\begin{array}{l}\text { 1000-grain } \\
\text { weight (g) }\end{array}$} & $\mathbf{P}$ & & & & & & & 1.000 & $0.284^{*}$ & $0.420^{* *}$ & $0.607^{* *}$ \\
\hline & $\mathbf{G}$ & & & & & & & 1.000 & $0.293^{* *}$ & $0.456^{* * *}$ & $0.645^{* *}$ \\
\hline \multirow{2}{*}{$\begin{array}{l}\text { Amylose } \\
\text { content (\%) }\end{array}$} & $\mathbf{P}$ & & & & & & & & 1.000 & $0.384^{* *}$ & 0.139 \\
\hline & $\mathbf{G}$ & & & & & & & & 1.000 & $0.412^{* *}$ & 0.157 \\
\hline \multirow{2}{*}{$\begin{array}{l}\text { Protein } \\
\text { content (\%) }\end{array}$} & $\mathbf{P}$ & & & & & & & & & 1.000 & 0.178 \\
\hline & $\mathbf{G}$ & & & & & & & & & 1.000 & 0.185 \\
\hline \multirow{2}{*}{$\begin{array}{l}\text { Grain yield } \\
\text { per plant (g) }\end{array}$} & $\mathbf{P}$ & & & & & & & & & & 1.000 \\
\hline & $\mathbf{G}$ & & & & & & & & & & 1.000 \\
\hline
\end{tabular}

$*$, ** Significant at $5 \%$ and $1 \%$ levels, respectively 
Table.2 Estimates of genotypic and phenotypic direct and indirect effects between yield and its attributing traits

\begin{tabular}{|c|c|c|c|c|c|c|c|c|c|c|c|}
\hline Characters & & $\begin{array}{c}\text { Days to } \\
50 \% \\
\text { flowering }\end{array}$ & $\begin{array}{l}\text { Days to } \\
\text { maturity }\end{array}$ & $\begin{array}{c}\text { Plant } \\
\text { height } \\
\text { (cm.) }\end{array}$ & $\begin{array}{c}\text { Number of } \\
\text { productive } \\
\text { tillers per } \\
\text { plant }\end{array}$ & $\begin{array}{c}\text { Panicle } \\
\text { length } \\
\text { (cm.) }\end{array}$ & $\begin{array}{c}\text { Number } \\
\text { of grains } \\
\text { per } \\
\text { panicle }\end{array}$ & $\begin{array}{l}\text { 1000- } \\
\text { grain } \\
\text { weight } \\
\text { (g) }\end{array}$ & $\begin{array}{c}\text { Amylose } \\
\text { content } \\
(\%)\end{array}$ & $\begin{array}{c}\text { Protein } \\
\text { content } \\
(\%)\end{array}$ & $\begin{array}{c}\text { Correlation } \\
\text { with grain } \\
\text { yield per } \\
\text { plant }\end{array}$ \\
\hline \multirow[b]{2}{*}{$\begin{array}{l}\text { Days to } 50 \% \\
\text { flowering }\end{array}$} & $\mathbf{P}$ & 0.5771 & -0.5302 & 0.0029 & 0.2367 & -0.0711 & -0.0585 & 0.1273 & 0.0015 & 0.0078 & $0.294^{* *}$ \\
\hline & $\mathbf{G}$ & 0.0607 & 0.0199 & 0.2224 & 0.3067 & -0.1418 & -0.1971 & 0.0645 & -0.0319 & 0.0047 & $0.308 * *$ \\
\hline \multirow[b]{2}{*}{ Days to maturity } & $\mathbf{P}$ & 0.5633 & -0.5431 & 0.0030 & 0.2525 & -0.0768 & -0.0570 & 0.1457 & 0.0014 & 0.0041 & $0.293^{* *}$ \\
\hline & $\mathbf{G}$ & 0.0606 & 0.0199 & 0.2261 & 0.3248 & -0.1503 & -0.2025 & 0.0745 & -0.0295 & 0.0019 & $0.325^{* *}$ \\
\hline \multirow[b]{2}{*}{ Plant height( cm) } & $\mathbf{P}$ & 0.4350 & -0.4167 & 0.0038 & 0.2190 & -0.0689 & -0.0443 & 0.1443 & 0.0011 & 0.0106 & $0.284^{*}$ \\
\hline & G & 0.0562 & 0.0187 & 0.2402 & 0.3580 & -0.1584 & -0.1763 & 0.0925 & -0.0287 & 0.0069 & $0.409^{* *}$ \\
\hline \multirow{2}{*}{$\begin{array}{l}\text { Number of productive } \\
\text { tillers per plant }\end{array}$} & $\mathbf{P}$ & 0.1745 & -0.1752 & 0.0011 & 0.7826 & -0.0481 & -0.0166 & 0.1851 & -0.0004 & -0.0224 & $0.881^{* *}$ \\
\hline & $\mathbf{G}$ & 0.0199 & 0.0069 & 0.0921 & 0.9336 & -0.1087 & -0.0478 & 0.1000 & 0.0082 & -0.0109 & $0.993^{* *}$ \\
\hline Panicle length( $\mathrm{cm}$ ) & $\mathbf{P}$ & 0.3378 & -0.3434 & 0.0022 & 0.3100 & -0.1214 & -0.0316 & 0.2183 & -0.0002 & -0.0033 & $0.369^{* *}$ \\
\hline \multirow{2}{*}{$\begin{array}{l}\text { Number of grains per } \\
\text { panicle }\end{array}$} & $\mathbf{P}$ & 0.4005 & -0.3675 & 0.0020 & 0.1540 & -0.0455 & -0.0843 & 0.0922 & 0.0011 & -0.0069 & 0.146 \\
\hline & $\mathbf{G}$ & 0.0583 & 0.0197 & 0.2065 & 0.2176 & -0.1164 & -0.2051 & 0.0590 & -0.0324 & -0.0035 & 0.204 \\
\hline \multirow[t]{2}{*}{ 1000-grain weight(g) } & $\mathbf{P}$ & 0.2092 & -0.2252 & 0.0016 & 0.4125 & -0.0755 & -0.0221 & 0.3513 & -0.0009 & -0.0438 & $0.607^{* * *}$ \\
\hline & $\mathbf{G}$ & 0.0226 & 0.0086 & 0.1283 & 0.5388 & -0.1523 & -0.0698 & 0.1732 & 0.0195 & -0.0238 & $0.645^{* *}$ \\
\hline \multirow[t]{2}{*}{ Amylose content ( \%) } & $\mathbf{P}$ & -0.2575 & 0.2272 & -0.0013 & 0.0919 & -0.0058 & 0.0282 & 0.0997 & -0.0033 & -0.0401 & 0.139 \\
\hline & $\mathbf{G}$ & -0.0292 & -0.0089 & -0.1040 & 0.1158 & -0.0128 & 0.1001 & 0.0508 & 0.0663 & -0.0215 & 0.157 \\
\hline \multirow[t]{2}{*}{ Protein content( \%) } & $\mathbf{P}$ & -0.0429 & 0.0215 & -0.0004 & 0.1677 & -0.0038 & -0.0055 & 0.1474 & -0.0013 & -0.1044 & 0.178 \\
\hline & $\mathbf{G}$ & -0.0054 & -0.0007 & -0.0320 & 0.1956 & -0.0129 & -0.0138 & 0.0790 & 0.0273 & -0.0521 & 0.185 \\
\hline
\end{tabular}

Phenotypic residual effect $=0.16229$, Genotypic residual effect $=0.1819$ 
Fig.1 Diagrammatical presentation of genotypic correlation coefficient for 10 Characters in rice genotypes

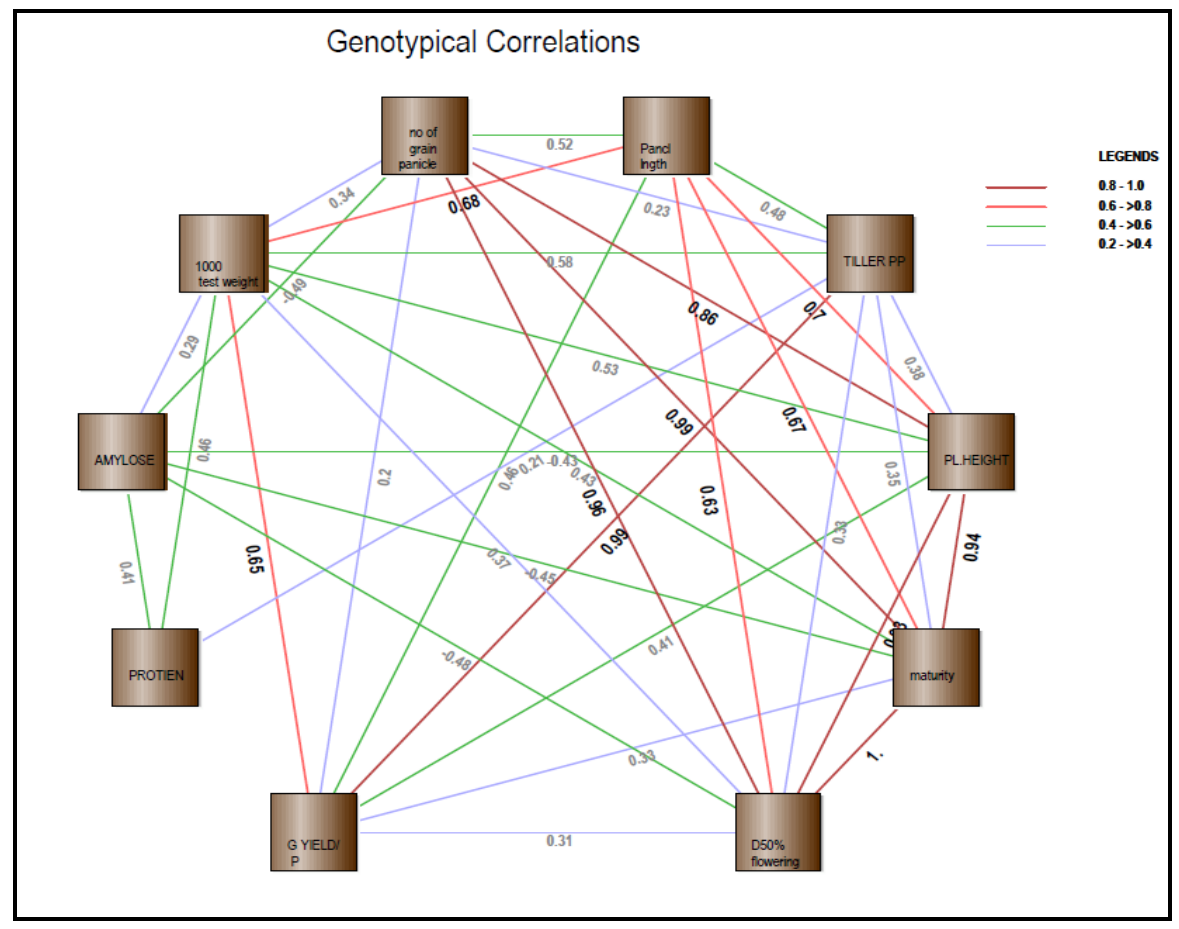

Fig.2 Genotypic path diagram for grain yield per plant

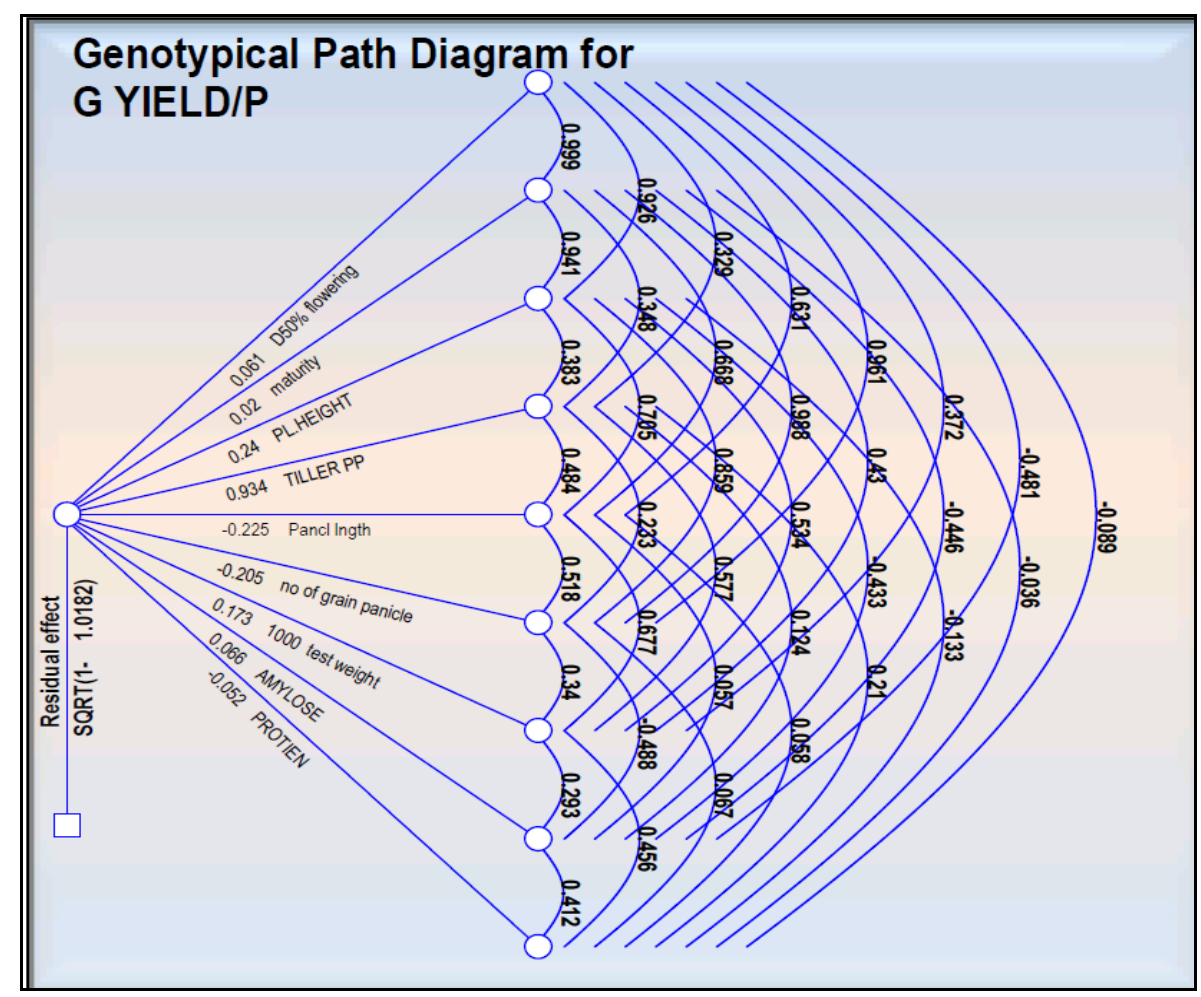


Grain yield per plant was positively and significant correlated with characters viz., days to 50 per cent flowering, days to maturity, plant height, number of productive tillers per plant, panicle length and 1000-grain weight at phenotypic and genotypic levels, respectively indicating grain yield of rice can be improved by selecting genotypes having higher values for these traits. These results were in accordance with the results of Rajamadhan et al., (2011), Limbani et al., (2017), Priya et al., (2017), Sangare (2017), Edukondalu et al., (2017), Kumar V. and Sonali K. ( 2018).

The correlation of days to 50 per cent flowering was positively and significantly correlated with days to maturity, plant height, number of productive tillers per plant, panicle length, grains per panicle, 1000-grain weight and grain yield per plant at both the levels whereas days to maturity had positive and significantly correlation with plant height, number of productive tillers per plant, panicle length, grains per panicle and 1000-grains weight and grain yield per plant. Plant height was significantly and positively correlated with number of productive tillers per plant, panicle length, number of grains per panicle, 1000-grain weight and grain yield per plant.

Positive and significant correlation of number of productive tillers per plant was observed with panicle length, 1000-grains weight, number of grain per panicle and grain yield per plant and at genotypic level. Panicle length was positively and significantly correlated with grain per panicle, 1000-grains weight and grain yield per plant whereas number of grains per panicle had positive and significant correlation with 1000-grains weight.

Positive and significant correlation of 1000grains weight was recorded with amylose content, protein content and grain yield per plant. Amylose content was positively and significantly correlated with protein content. Path coefficient analysis result (Table 2) revealed that, maximum direct positive effect on grain yield per plant was observed for number of productive tillers per plant followed by 1000-grains weight, panicle length, plant height, days to maturity and days to 50 per cent flowering at both the levels, respectively.

These results are in agreement to the earlier finding of Khare et al., (2015) Hijam et al., (2017), Sowjanya et al., (2017) and Monalisha et al., (2018). The high positive association of other characters with grain yield per plant was also due to high indirect effect through these characters. On the other hand, negative direct effect on grain yield per plant at was exhibited by panicle length, number of grains per panicle and protein per cent and at genotypic level whereas, at phenotypic level negative direct effect on grain yield per plant was exhibited by days to maturity, panicle length, number of grains per panicle, amylose content and protein content. Jan et al., (2017), Monalisha et al., (2018) reported similar findings earlier.

Among all the characters, at genotypic level number of productive tillers per plant( 0.9336) had the maximum direct effect followed by plant height (0.2402), 1000grains weight (0.1732), amylose content (0.0663), days to 50 per cent flowering (0.0607) and days to maturity (0.0199). On the other hand, negative direct effect were observed for panicle length (-0.2248), number of grains per panicle $(-0.2051)$ and protein content (-0.0521). At phenotypic level higher direct effect was observe for number of productive tillers per plant $(0.7826)$ followed by days to 50 per cent flowering (0.5771), days to maturity (0.5431), 1000-grain weight (0.3513) and plant height (0.038). 


\section{References}

Anonymous, (2018-19). Agriculture Statistics at a Glance, Directorate of Economics \& Statistics, Department of Agriculture \& Cooperation, Ministry of Agriculture. Government of India.

Anonymous, (2018-19). Rajasthan Agriculture statistics at a Glance, Commissionarate of Agriculture, Rajasthan, Jaipur.

Dewy, D.R. and Lu, K.H.( 1959). A correlation and path coefficient analysis of components of crested wheat grass seed production. Journal of Agronomy, 51: 515- 518.

Edukondalu, B., Reddy, V.R., Rani, T.S., Kumari, C.A. and Soundharya, B. ( 2017). Studies on Variability, Heritability, Correlation and Path Analysis for Yield, Yield Attributes in Rice (Oryza sativa L.). International Journal of Current Microbiology Applied Science, 6(10): 2369-2376.

Hijam, L., Sarkar, K.K. and Mukherjee, S.(2017). Inheritance and association of yield and its attributing traits in rice (Oryza sativa L.). Journal of Crop and Weed, 13(1): 64-71.

Jan, N., Lal, E.P., Kashyap, S.C. and Gaur, A. (2017). Genetic variability, character association and path analysis studies for contributing traits in rice (Oryza sativa L.) under temperate conditions of Kashmir. Vegetos- An International Journal of Plant Research, 30(2): 1-7.

Khare, R., Singh, A.K. and Singh, P.K. (2015). Genetic variability association and diversity analysis in upland rice (Oryza sativa L). SAARC Journal of Agriculture, 12(2): 40-51.

Kumar, V. and Sonali K. (2018). Association analysis of native rice (Oryza sativa L.) of Bastar. Electronic Journal of Plant Breeding, 9(1): 199-212.
Limbani, P.L., Gangani, M.K. and Pandya, M.M. (2017). Genetic Variability, heritability and genetic advance in rice (Oryza sativa L.). International Journal of Pure \& Applied Biosciences.5( 6): 1364-1371.

Monalisha, P. and Das, S.R. (2018). Genetic variability, correlation and path analysis in hybrid rice. International Journal of Agriculture Sciences, 10(14): 6691-6693.

Priya, S., Suneetha, Y., Babu, D.R. and Rao, V.S. (2017). Inter-relationship and path analysis for yield and quality characters in rice (Oryza sativa L.). International Journal of Science, Environment and Technology, 6(1): 381-390.

Rajamadhan, R., Eswaran, R. and Anandan, A. (2011). Investigation of correlation between traits and path analysis of rice (Oryza sativa L.) grain yield under coastal salinity. Electronic Journal of Plant Breeding, 2(4): 538-542.

Sangaré, J.R., Konaté, A.K., Cissé, F. and Sanni, A. (2017). Assessment of genetic parameters for yield and yield related-traits in an intraspecific rice (Oryza sativa L.) population. Journal of Plant Breeding and Genetics, 5(2): 45-56.

Singh, R.K. and choudhary, B.D. (1979). Biometrical methods in quantative genetic analysis. Kalyani Publishers. Ludhiana and Delhi.

Sowjanya, P.R., Raghavendra, P. and Shailaja, H. (2017). Trait association studies to determine selection indices in two $\mathrm{F}_{3}$ segregating populations of rice (Oryza sativa L.) under aerobic condition. Oryza, 54(3): 276-281.

Wright, S. (1921). Correlation and causation. Journal of Agriculture Research, 20: 257287.

\section{How to cite this article:}

Deepak Meena, Manoj Kumar, Sandhya, N. R. Koli, Yamini Tak and Ashok Kumar Meena. 2020. Assessment of Correlation and Path Coefficient Analysis for Yield and it's Attributing Traits in Rice (Oryza sativa L.) Genotypes. Int.J.Curr.Microbiol.App.Sci. 9(07): 3845-3851. doi: https://doi.org/10.20546/ijcmas.2020.907.450 